УДК 502.13:004.4

DOI: https://doi.org/10.26642/jen-2020-2(92)-15-2

В.В. Микитенко, д.е.н., проф. I.В. Драган, к.е.н., доц. ДУ «Інститут економіки природокористування та сталого розвитку НАН України»

\title{
Інформаційно-методичні аспекти розбудови платформ просторового управління природними активами в ресурсних обмеженнях
}

\begin{abstract}
У статті розроблено та обтрунтовано інформаційно-методичні основи розбудови платформ просторового управління природно-ресурсними активами, опрацювання яких виконано за використання положень синергетичного та структурно-інформачійного підходів до формування прикладного інструментарію оцінювання $i$ зустрічного прогнозування масштабів освоєння й використання природно-ресурсних активів держави та ї̈ регіонів. Передбачено побудову, в межах підсистем функиіональної та прийняття рімень $i$ розвитку комунікативного метапростору (щз належить до просторової системи управляння), сталих теоретикоаналітичних $i$ прикладних моделей із високим ступенем апроксимації характеристик та порівняльної оцінки оптимальних з метою залучення в межах бізнес-екосистем України існуючих природних активів у контексті формування національної економіки платформного типу за наслідками посилення конкурентних позицій учасників сталого господарювання й підвищення результативності просторового управління. Доведено, щуо застосування інформаційнометодичних платформ за єдиним форматом дочільне для використання експертами й користувачами різних управлінських рівнів. Удосконалено структуру, зміст $i$ функціі інформаційно-методичного забезпечення системи просторового управління природно-ресурсними активами платформного типу. До його складу враховано комплекс иільових програм MiNerGy v.5.0 i MINprojet v.3, де за алгоритмом із двох блоків для виконання економіко-статистичного $i$ стохастичного зустрічного прогнозів використано, поряд зі стандартними пакетами «Statistica +» ma Windows-додатків Excel, Access (належать до авторських технологій), інструментальне середовище когнітивно-інформаційних систем третього інтелектуального рівня, які розроблено за використання нейронних мереж Neiro Pro 0,25 ma Brain Maker 3.11.
\end{abstract}

Ключові слова: інформачійне забезпечення; просторова система управління; сталий розвиток; управління природно-ресурсними активами.

Вступ. Аналіз сучасної економічної ситуації у світі свідчить про наростання процесів нестабільності та мінливості глобальної економіки, яка характеризується: високою невизначеністю валютних i сировинних ринків; геополітичними процесами переділу впливу держав на світовий розвиток; соціальними процесами перерозподілу доходів між верствами суспільства, які супроводжуються економічною міграцією; геокліматичними змінами, що значно впливають на економіку; науковотехнічним прогресом, що змінює структуру виробництва і споживання; а також іншими процесами, що порушують проблему коригування системи управління природно-ресурсними активами.

Аналіз попередніх досліджень та публікацій. Теоретичним, методологічним і прикладним аспектам вирішення багатогранних проблем щодо розробки й обгрунтування інформаційних аспектів розбудови платформ просторового управління природно-ресурсними активами присвячено наукові праці О.Алимова, О.Амоші, Б.Данилишина, С.Дорогунцова, Л.Кузьменко, І.Лукінова, М.Чумаченко, С.Шкарлета та інших вчених-економістів. Методичні підходи щодо дослідження проблематики i моделювання траєкторії розвитку національних соціально-економічних систем розкрито в роботах І.Ансоффа, О.Віханського, А.Касич, М.Портера, А.Стікленда, А.Томпсона, О.Федоніна, М.Хвесика.

Мета статті - розробка та обгрунтування інформаційно-методичних основ розбудови та використання в державі платформ просторового управління природно-ресурсними активами.

Викладення основного матеріалу. Формування просторової системи управління природноресурсними активами на платформних засадах вимагає, насамперед, дослідження внутрішніх платформних взаємодій та застосування у їхніх межах цільового програмного забезпечення для моделювання наслідків прийняття управлінських рішень на базі об'єктивної системи показників зі специфічними властивостями, інкорпорованої до їхніх програмних блоків. Їх опрацювання, на переконання авторів, слід здійснити за використання положень синергетичного й структурноінформаційного підходів до розроблення прикладного інструментарію оцінювання та зустрічного прогнозування масштабів освоєння і використання природно-ресурсних активів держави та іiі регіонів. Зазначимо, що в межах останніх, на відміну від існуючих, слід інкорпорувати до базових підсистем (функціональної та прийняття рішень і розвитку комунікативного метапростору) сталі теоретико- 
аналітичні і прикладні моделі із високим ступенем апроксимації характеристик та порівняльної оцінки оптимальних 3 метою залучення в межах національних бізнес-екосистем існуючих природних активів. Вказане вище має спрямовуватися на розбудову/ формування в Україні національної економіки платформного типу за наслідками посилення конкурентних позицій учасників сталого господарювання i підвищення результативності просторового управління.

Відповідно до цього визнаємо, що інформаційна теорія дослідження та обчислення параметрів надійності функціонування та розвитку просторової системи у контексті забезпечення переходу держави та іiі регіонів до сталого розвитку в ресурсних обмеженнях $\epsilon$ надзвичайно складним комплексним завданням, яке торкається практично всіх функціональних напрямів діяльності національної соціальноекономічної системи та природно-ресурсного потенціалу держави. Адже під час формування загальних чи специфічних вимог саме до мінімаксних - граничних значень показників у межах цільового програмного забезпечення у просторі певної платформи слід звертати увагу на те, що останні перетинаються з окремими (але декількома одночасно) сферами та процесами стратегічного управління, насамперед, під час формулювання та кількісної інтерпретації стратегічних інтересів реального сектору економіки, екології, медико-соціального забезпечення i, відповідно, базових для України видів економічної діяльності [4].

Відтак й інформаційно-методичні положення дослідження просторової системи управління природно-ресурсними активами (ПСУ сталого розвитку держави, регіонів і певних територій та бути адекватно прийнятими щодо реалізації в Україні ऑї функціональним стратегіям, а саме: інноваційно-інвестиційній, сировинно-ресурсній, екологічній, промисловій, соціальній та регіональним. Однак програмний апарат платформного типу має бути доступним експертам і користувачам різних управлінських рівнів. Тому використання певного складу показників, критеріїв та індикаторів має узгоджуватися 3 нею. Адже забезпечення відповідності вимогам, єдності моделей сталого розвитку, освоєння природно-ресурсних активів, взаємозалежності та взаємостимулювання ресурсних, енерго-економічних, інноваційних, техніко-технологічних й інших процесів забезпечує єдність методичної бази просторового управління на сучасному етапі розвитку національної економіки та ії базових галузей [3].

Крім того, оцінка природно-ресурсних активів, прогноз тенденцій їх освоєння та рівнів ресурсо- й енергоємності пов'язана 3 комплексом проблем, що виникли за сучасних умов функціонування економіки України. Процеси просторового управління природно-ресурсними активами та їх використання вимагають об'єктивної, повної інформації про показники, які, окрім базових економічних, екологічних і соціальних параметрів розвитку, характеризують ще й причини, які обумовлюють їх зміну. Тож для потреб довгострокового прогнозування макроекономічних показників, управління й регулювання економічною, екологічною та соціальною сферами виникла необхідність впровадження спеціальної методології та особливих математичних, технічних, технологічних і платформних програмних засобів.

Для забезпечення єдиного підходу до оцінки ступеня дотримання інтересів, вірогідності прогнозів, реалізованості стратегій та досягнення цілей у ресурсних обмеженнях слід забезпечити єдність характеру значень показників, що використовуються. Фактичні та ретроспективні показники характеризуються найвищим рівнем вірогідності, оскільки саме вони фіксують досягнуті результати. Нижчим рівнем планові, оскільки відображають передбачуваний стан промисловості та результати його діяльності. Найменшим - показники кількісної оцінки національних інтересів, до яких ставляться найбільш високі вимоги з погляду обгрунтованості, оскільки вони є базою для прийняття стратегічних рішень, наприклад, інвестиційної підтримки, реструктуризації чи модернізації національного господарства відповідно до величини наявних ресурсів.

Таким чином, система дослідження та обчислення параметрів еволюції ПСУпрА має містити сукупність послідовних і взаємозалежних блоків та етапів діяльності науково-методологічного й прикладного характеру, систематизованих і зорієнтованих на універсальні методики експресдіагностики, методи та моделі адаптивного управління в ресурсних обмеженнях. При цьому слід вказати, що вона може суперечити процесам забезпечення сталого розвитку держави або ж певної території, визначати пріоритети та обсяги підтримки інвестиційних проєктів, що дозволяє підвищити рівень результативності управління природно-ресурсними активами та захисту навколишнього середовища; забезпечувати відповідність загальних та специфічних вимог до ресурсно-функціонального забезпечення діяльності національного господарства [1; 2].

За умови використання платформного інструментарію є реальна можливість виявити та оцінити вплив ризику на стійку позитивну динаміку розвитку бізнес-екосистем, сформувати організаційноекономічний механізм забезпечення сталого розвитку i, одночасно, раціоналізації використання стратегічного потенціалу держави тощо. Поряд із цим, розроблений інструментарій дозволить обгрунтувати та обрати адекватні реальним процесам способи і засоби макроекономічного регулювання. Тож саме розроблення алгоритму побудови платформної системи інформаційних каналів та формування 
об'єктивних комп'ютерних баз даних 3 використанням цільового пакета авторського програмного забезпечення доводить нагальність запровадження останнього і забезпечення безперервності технікоекономічного прогнозування масштабів природно-ресурсних активів держави та їх освоєння на різні терміни упередження.

Опрацювання інформаційно-методичного програмного забезпечення («MainStreaM. Pro Platform Software v.1.1») з метою формування платформної економіки вимагає посилення гнучкості управлінських технологій за рахунок використання цільового програмного продукту MiNerGy v.5.0 та MINprojet v.3, де в алгоритмі двох блоків за економіко-статистичним прогнозом використано інструментальне середовище інтелектуальних систем на основі нейронних мереж Neiro Pro 0,25 та Brain Maker 3.11 і стандартні пакети «Statistica» та Windows-додатки Excel, Access, які входять до авторських IT MINPro та MINgraf, що упорядковує систему контролю за макроекономічними результатами діяльності у сфері просторового управління природно-ресурсними активами України.

3 огляду на це слід заначити, що використання системно-блочного абстрактного моделювання $\mathrm{i}$ прогнозного тренування, використання методики експрес-діагностики ПСУ ПрА у складі з п'яти блоків іiі елементів та складу оточення як більш або менш самостійних систем забезпечує єдність аналізу і синтезу. А це, насамперед, обумовлено значним синергічним ефектом від вдосконалення когнітивноінформаційних комунікацій та самої інформаційно-методичної діяльності. За таких умов неможливість передбачення подій із великим ступенем вірогідності компенсується саме формуванням значного масиву інформації в межах «MainStreaM. Pro Platform Software v.1.1», що одержала кількісну оцінку на підставі аналізу сукупності різної природи процесів (розроблення базується на блоках цільових програм [5]).

Відтак можна провести аналогію між інформаційними платформними технологіями та технологіями віртуальної реальності, опис під час поєднання елементів яких обгрунтовує доцільність використання інформаційної структурної теорій систем і синергії; під час використання яких можливим є створення гнучких комп'ютерних моделей у межах єдиної платформи задля визначення напрямів одночасного розвитку багатокомпонентних систем - економічних, енергоекономічних, екологічних, ресурсних, виробничих, соціальних та операційних. Цим можна довільно маніпулювати та варіювати. Завдяки тому, що сучасна комп'ютерна техніка дає можливість антропоморфізувати вхідну та вихідну аналітичні бази досліджень, надати їм типологічної визначеності, виокремити необхідні показники, здійснити їх розподіл за інформаційними програмами, оператор (експерт платформи) отримує можливість звичним механічним способом провести прогнозне тренування й моделювання пріоритетів, розроблення моделей освоєння природно-ресурсних активів, маніпулюючи вхідною інформацією та вагомістю впливів тих чи інших параметрів на сталий розвиток території.

Таким чином, визнаємо, що в основі акомодації платформних IT до науково-аналітичної діяльності управління просторовим розвитком міститься ідея, суть якої полягає у тому, що за допомогою відповідного програмного забезпечення, інкорпорованого до єдиної платформи, можна створити моделі контрольованих світів, економік, систем, мереж чи процесів. При цьому є можливість, зі значним ступенем достовірності, розробити для них проєкт місії, оптимальний варіант структури чи безпечний напрям зрушень залежно від бажання досягнути певних макроекономічних показників, термінів випередження подій, цілей сталого розвитку об'єктів та швидкості зміни орієнтирів суб'єктів управління.

Поряд із цим зауважимо, що користувач платформних програмно-технічних комплексів, змінюючи алгоритми і завдання, опрацьовує превентивні заходи, запобігаючи загрозам позитивній динаміці розвитку та проявам гострої кризи у певній сфері діяльності; прораховує ймовірні ризики під час зміни умов та складових стратегічного потенціалу з побудовою матриць кореляції між базовими показниками; оцінює майбутній стан певного природно-ресурсного активу 3 погляду найважливіших процесів, що відображають їх сутність; формує систему показників-індикаторів із обгрунтуванням бажаних та допустимих граничних меж їх кількісного вираження, вихід за які $є$ свідченням втрати здатності національної соціально-економічної системи до саморозвитку і прогресу. Оскільки сучасні процеси в національному господарстві супроводжуються обміном необмеженої кількості даних, то синергетика та структурно-інформаційна теорія систем за своїм характером і специфічними можливостями найбільше відповідають принципам відбору й поєднання інформації, окреслюючи перелік вагомих факторів та основних параметрів порядку, від поєднання яких залежить вектор та якість розвитку ПСУ пРА.

3 огляду на це, спрямування та синтез інформаційних потоків у поєднанні з розробкою цільових платформних програм, відповідно до запропонованих у цьому досліджені теоретико-концептуальних основ формування ПСУ ПРА, змінюють розуміння та ймовірність прогнозів, закладаючи основи для іiі органічного функціонування в межах нестійкої на сучасному етапі розвитку національної соціальноекономічної системи. Доцільно зазначити, що існуючі прогалини у забезпеченні достатньої ефективності управління інформаційним потенціалом можна заповнити за допомогою нуклеаційної функції, яка спершу встановлюється в кінцевій області бази даних на єдиній платформі, i лише потім розповсюджується на весь інформативний простір управління. Мультиплікатором при цьому фігуруватиме компенсуючий синергічний ефект, що виникає у процесі формування ПСУ ПрА. 
Крім того, надійність та вартість інформації мають розумні межі та економічні витрати. 3 огляду на це, зауважуємо і те, що сучасна кібернетично-віртуальна реальність, яка характеризує інформаційноекономіко-виробниче суспільство, сприяє багатофакторному аналізу та осмисленню його місії використовуючи різнопланові підходи. Водночас пріоритетним залишається інформаційносинергетичний підхід до інформаційно-методичного забезпечення платформної економіки. Тож завдяки його використанню передбачаються сфери й обсяги концентрації зусиль та стратегічних об'єктів природно-ресурсних активів, виводиться модель їх освоєння та використання, що як своєрідний атрактор, концентруючи та упорядковуючи навколо себе потоки інформації, породжує вивірені центри тяжіння елементів між компонентами просторової системи управління, що упорядковує рух інформації та вибірковість аналізу зустрічних потоків, виокремлюючи вагомішу з них. Тому в таблиці 1 авторами репрезентовано три основні властивості системи показників та статистичної інформації, які й забезпечать необхідний рівень обгрунтованості дослідження та обчислення параметрів ПСУ ПрА за форматом платформної економіки.

До них, зокрема, належать: спостережливість - здатність простежувати параметри стану, що швидко змінюються; прогнозованість - теж саме відносно параметрів майбутнього стану; ідентифікація - теж саме для параметрів структури, що можуть вважатися незмінними. Дотримання зазначених особливостей $\epsilon$ важливим і під час розгляду процесів просторового управління у реальному часі, і під час зіставлення темпів корегування управлінських дій та уточнення інформації про умови функціонування і розвитку національного господарства, галузей і технологій. Також зазначимо, що спостережливість залежить від відповідності економіко-математичних моделей визначеним моделям розвитку національної соціальноекономічної системи та від масштабів змінних, які описують їх стан.

Вимоги до інформаційних властивостей системи показників та статистичної інформації у межах платформ управління

\begin{tabular}{|c|l|c|}
\hline $\begin{array}{c}\text { Властивість } \\
\text { системи показників }\end{array}$ & \multicolumn{1}{|c|}{ Сутність інформаційної властивості платформ управління } \\
та їх дефініційне визначення
\end{tabular}

Доцільне впровадження і врахування такої системи масштабів, яка б відтворювала абсолютну цінність інформації для кожного функціонального рівня просторового управління природно-ресурсними активами. При цьому зазначене вище можливе лише за умови наявності (обгрунтування й розробки) єдиного критерію оцінки досліджуваних процесів, тобто з освоєння і використання активів, а також прогнозування ефективності функціонування національного господарства в цілому. 
Тож підсумовуючи зазначене вище, можемо констатувати, що обчислений за сформованим комплексом еколого-, соціо- й ресурсо-економічних моделей узагальнений інтегральний показникіндикатор результативності просторового управління природно-ресурсними активами (більш ніж імовірно, це не 2-х, 3-х, 5-ти, а більше факторний) є критерієм, який не просто вказує у кількісному виразі на ефективне чи неефективне використання природно-ресурсних активів, а й оцінює та дозволяє прогнозувати їх рівень на певний період упередження. Оскільки кількісну оцінку результативності просторового управління буде одержано за допомогою відносного формату абсолютних показників, які використовуються в статистичних розрахунках, плануванні, обліку й аналізі діяльності досліджуваної сфери управління, то існують реальні підстави для обчислення граничних (мінімаксних) значень критерію, що $\epsilon$ передумовою практичного використання агрегованих показників-індикаторів результативності в межах системи національних рахунків (СНP).

Універсальні методи та моделі, що запропоновані у цьому дослідженні для платформної оцінки та прогнозування масштабів освоєння і використання природно-ресурсних активів України, мають й інші інформаційні властивості. А саме: а) адаптованість, в яку вкладаються функціональні завдання щодо врахування та відтворення у математичному образі економіко-математичних рішень фактора поступового старіння вхідної інформації; б) рекурентність вихідних показників, що відтворюватиме корекцію математичного опису елементів у процесі зміни складових природно-ресурсного активу держави чи заміни технологій їх освоєння та використання.

Зауважимо, що розроблені авторами методики (експрес-діагностики, чотирьохрівневого прогнозу, обчислення прогнозів макроекономічних показників, побудови системи показників-індикаторів, критеріїв результативності просторового управління 3 використанням платформного комплексу модельних рішень) підтвердили якість опрацьованих підходів до обробки інформації, формування прикладного інструментарію та цільового пакета програмного забезпечення за різними версіями оригінальної цільової програми «MainStreaM. Pro Platform Software v.1.1» щодо їх відповідності вимогам до інформаційно-методичного забезпечення. Тобто - науковість, систематичність, комплексність, оперативність, регулярність, об'єктивність, економічність, точність, обгрунтованість, репрезентативність і релевантність.

На авторське переконання, найбільш повне виявлення внутрішньогалузевих резервів і отримання передбаченого ефекту від просторового управління процесами освоєння та використання природноресурсних активів держави можливе лише у випадку поелементного їх розгляду. Отже, основним завданням проєктного аналізу за платформним форматом є визначення напрямів і шляхів оптимізації використання природно-ресурсних активів у перспективному періоді. Тобто завдання можна сформулювати таким чином: замість збільшення обсягів освоєння активів - оптимальне їх використання. На думку авторів, під час оцінки та прогнозу важливішим є отримати взаємно збалансовані кількісні оцінки 3 якісним аналізом переваг тих чи інших варіантів, що забезпечить управління достовірною інформацією про обсяги та види споживання [7; 8].

Джерелом вихідної інформації проведеного дослідження та обчислення параметрів просторової системи управління мають стати існуючі офіційні дані Державної служби статистики України, документи статистичної звітності, річні звіти господарської діяльності видобувних і переробних підприємств, техніко-економічні характеристики проєктів. Економічний аналіз цих матеріалів 3 використанням інформаційного забезпечення, розробленого у межах цього дослідження, дозволить отримати показники, на базі яких здійснювалося моделювання динаміки розвитку досліджуваної сфери діяльності, прогноз макропоказників і вибір моделі сталого розвитку зростання з урахуванням досвіду країн світу [6]. При цьому застосування IT платформного типу під час формування, моделювання динаміки та обчислення параметрів просторової системи дозволить об'єднати декілька робочих процедур в одну, одночасно прискорюючи у кілька разів аналіз результатів та скорочуючи терміни розроблення прогнозу показників результативності на різні терміни упередження. Відтак можемо засвідчити: IT та їх інструментальне вирішення платформного типу, згідно з особливостями впливу масштабів освоєння природно-ресурсних активів на технологічне зростання, можна розрізняти за групами, що забезпечують у визначеній площині:

I - активізацію заходів по забезпеченню сталого розвитку територій за рахунок автоматизації технологічних процесів;

II - появу й активізацію проривних процесів, що дозволяють перейти до нових вимог і правил оцінювання та прогнозування результативності просторового управління природно-ресурсними активами.

Результати системного подання даних та виокремлення нових принципів формування платформного цільового інформаційного забезпечення, подальше дефініційне визначення та визначення функціонального змісту основних понять і термінів цільового пакета платформного програмного забезпечення «MainStreaM. Pro Platform Software v.1.1», а також формалізація архітектури платформного пакета програмного забезпечення задля оцінки й прогнозу результативності просторового управління природно-ресурсними активами за авторською програмою «MainStreaM. Pro Platform Software v.1.1» дозволяють засвідчити: 
- $\quad$ нагальність і доцільність використання відповідних програм платформного типу з урахуванням їхніх переваг щодо створення відповідних просторових структур у інших видах діяльності задля продовження дослідницької і науково-практичної роботи над новими «проривними» рішеннями стосовно вдосконалення механізмів просторового управління 3 метою досягнення бажаних результатів за наслідками реалізації їх дії;

- поширення досвіду використання розроблених методів, методик та практичного інструментарію забезпечення результативності просторового управління на інші сектори національного господарства 3 концентрацією зусиль на їх вдосконаленні й адаптації з урахуванням вимог до вибору та запровадження найбільш необхідних та ефективних технологій управління.

Висновки. Авторами обгрунтовано практичний організаційно-економічний підхід щодо формування платформного апаратного комплексу цільових програм із просторового управління природноресурсними активами на єдиній інформаційній основі третього інтелектуального рівня. Його розробка спирається на: а) добір системи показників за трьома інформаційними властивостями (прогнозованість, спостережливість, ідентифікація); б) врахування вагомості впливу платформної технології на об’єктивність вихідної бази даних; в) використання в ії̈ межах специфічного практичного інструментарію прогнозного тренування й прогнозування (за програмою «MainStreaM. Pro Platform Software v.1.1») у контексті перебудови національної економіки за платформним форматом. Зазначене забезпечує посилення гнучкості управлінських технологій, впорядковує систему контролювання за макроекономічними результатами діяльності та результативність регулювання масштабів освоєння i використання природно-ресурсного потенціалу держави, регіонів та певних територій в умовах ресурсних обмежень під час наростання суспільно-політичних загроз і ризиків.

\section{Список використаної літератури:}

1. Алимов О.М. Каскади регіональних соціально-економічних систем: формування та розвиток : монографія / О.М. Алимов, О.О. Демешок, І.В. Драган. - Київ : ДУ «Інститут економіки природокористування та сталого розвитку НАН України», 2016. - 278 с.

2. Алимов O.M. Потенціал сталого розвитку України на шляху реалізації інтеграційного вибору держави : монографія / О.М. Алимов, Л.С. Ладонько, І.М. Лицур. - Київ : ДУ «Інститут економіки природокористування та сталого розвитку НАН України», 2014. - 520 с.

3. Бистряков I.K. Переформатування просторової системи управління природно-ресурсними активами / I.К. Бистряков, B.B. Микитенко // Економіка природокористування і сталий розвиток : науковий журнал. Київ : ДУ «Інститут економіки природокористування та сталого розвитку НАН України», 2018. - № 1-2 (20-21). $-234 \mathrm{c}$.

4. Лицур I.M. Прогнозні можливості формування просторової системи управління природно-ресурсними активами / I.M. Лицур, В.В. Микитенко // Історія народного господарства та економічної думки України : всеукраїнський історико-економічний збірник наукових праць. - ДУ «Інститут економіки та прогнозування НАН України», 2018. - № 51. - С. 252-274.

5. А. с. 21784 Україна. Інформаційно-методичне забезпечення економічних досліджень: Цільове програмне забезпечення оцінки, прогнозу макроекономічних показників та рівня енергоефективності промислового виробництва (MINErgo v. 4.1) / В.B. Микитенко. - Опубл. : Офіційний бюлетень авторське право і суміжне право. - 2007. - № 13. - 3 с.

6. Національна парадигма сталого розвитку України : монографія / М.А. Хвесик, О.М. Алимов, А.В. Голян ma ін.; за заг. ред. академіка НАН України, д.т.н., проф., заслуженого діяча науки і техніки України Б.Є. Патона. - Вид. 2-ге, перероб. і доп. - Київ : ДУ «Інститут економіки природокористування та сталого розвитку НАН України», 2016. - $72 \mathrm{c}$.

7. Осипов Ю.М. Цифровая платформа как институт эпохи технологического прорыва / Ю.М. Осипов, Т.Н. Юдина, И.З. Гелисханов // Экономические стратегии. - 2018. - № 5. - С. 22-29.

8. Попело О.В. Теоретичні основи регіоналізації / О.В. Попело // Правове та інституційне забезпечення регіональної кластеризації : зб. мат-лів. Х Міжнародної науково-практичної конференції, 25 квітня 2018 р. : тези. - Чернігів : Чернігівський інститут ім. Героїв Крут, ПрАТ «ВНЗ» МАУП», 2018. - С. 100-108.

\section{References:}

1. Alymov, O.M., Demeshok O.O. and Drahan, I.V. et al. (2016), Kaskady rehional'nykh sotsial'no-ekonomichnykh system: formuvannia ta rozvytok, DU «Instytut ekonomiky pryrodokorystuvannia ta staloho rozvytku», Kyiv, Ukraine, $278 \mathrm{p}$.

2. Alymov, O.M., Demeshok, O.O. and Drahan, I.V. et al. (2014), Potentsial staloho rozvytku Ukrainy na shliakhu realizatsii intehratsijnoho vyboru derzhavy, DU «Instytut ekonomiky pryrodokorystuvannia ta staloho rozvytku NAN Ukrainy», Kyiv, Ukraine, 520 p.

3. Bystriakov, I.K. and Mykytenko, V.V. (2018), «Reformatting of the spatial system of management of natural resource assets», Ekonomika pryrodokorystuvannia i stalyj rozvytok, No. 1-2 (20-21), 234 p. 
4. Lytsur, I.M. and Mykytenko, V.V. (2018), «Predictive possibilities of formation of spatial system of management of natural resource assets», Istorija narodnogo gospodarstva ta ekonomichnoi' dumky Ukrai'ny, vseukrai'ns'kyj istoryko-ekonomichnyj zbirnyk naukovyh prac', No. 51. pp. 252-274.

5. Mykytenko, V.V. (2007), «Information and methodological support of economic research: Target software for estimation, forecast of macroeconomic indicators and level of energy efficiency of industrial production» (MINErgo v. 4.1), A. S. 21784 Ukraina, Ofitsijnyj biuleten' avtors'ke pravo i sumizhne pravo, No. 13, 3 p.

6. Khvesik, M.A., Alymov, O.M. and Golyan, A.V. et al. (2016), Natsional'na paradyhma staloho rozvytku Ukrainy, in Ph.D., prof. Paton, B.Je. (ed.), Derzhavna ustanova «Instytut ekonomiky pryrodokorystuvannia ta staloho rozvytku», Kyiv, Ukraine, $72 \mathrm{p}$.

7. Osipov, Yu.M., Yudina, T.N. and Geliskhanov, I.Z. (2018), «Digital platform as an institute of the era of technological breakthrough», Ekonomicheskie strategii, No. 5, pp. 22-29.

8. Popelo, O.V. (2018), «Teoretychni osnovy regionalizacii'», Pravove ta instytucijne zabezpechennja regional'noi' klasteryzacii', zb. mat-liv. H Mizhnarodnoi' naukovo-praktychnoi' konferencii', Chernihivs'kyj instytut im. Geroi'v Krut, PrAT «VNZ» MAUP», Chernihiv, Ukraine, pp. 100-108.

Микитенко Вікторія Володимирівна - доктор економічних наук, професор, головний науковий співробітник відділу методології сталого розвитку Державної установи «Інститут економіки природокористування та сталого розвитку Національної академії наук України», м. Київ.

Наукові інтереси:

- розробка й обгрунтування комплексу принципів, завдань i форм забезпечення сталого господарювання за врахування масштабів нагромадження загроз і ризиків різної природи.

http://orcid.org/0000-0002-8212-9777.

Драган Ірина Василівна - кандидат економічних наук, доцент, старший науковий співробітник відділу методології сталого розвитку Державної установи «Інститут економіки природокористування та сталого розвитку Національної академії наук України», м. Київ.

Наукові інтереси:

- науково-прикладні дослідження забезпечення загальної соціо-, еколого-економічної рівноваги та рекомендації щодо організації сталого господарювання.

http://orcid.org/0000-0002-6906-5000.

Стаття надійшла до редакції 10.03.2020. 